19 Revue d'histoire du XIXe siècle

Société d'histoire de la révolution de 1848 et des

révolutions du XIXe siècle

17 | 1998

Les foules au XIXe siècle

Remarques sur les foules religieuses en France au XIXe siècle (1815-1914)

Philippe Levillain

(2) OpenEdition

Journals

Electronic version

URL: http://journals.openedition.org/rh19/138

DOI: $10.4000 /$ rh19.138

ISSN: $1777-5329$

Publisher

La Société de 1848

Printed version

Date of publication: 1 December 1998

ISSN: 1265-1354

Electronic reference

Philippe Levillain, «Remarques sur les foules religieuses en France au XIXe siècle (1815-1914)», Revue d'histoire du XIXe siècle [Online], 17| 1998, Online since 10 September 2008, connection on 19 April 2019. URL : http://journals.openedition.org/rh19/138; DOI : 10.4000/rh19.138

This text was automatically generated on 19 April 2019

Tous droits réservés 


\section{Remarques sur les foules religieuses en France au XIXe siècle (1815-1914)}

Philippe Levillain

\section{ABSTRACTS}

No abstract available by now

Pas de résumé disponible actuellement

INDEX

Mots-clés: Foules 